\title{
PERKEMBANGAN MASYARAKAT TRANSMIGRASI DI DUSUN SIDOMULYO DESA LIMBUNG KECAMATAN SUNGAI RAYA KABUPATEN KUBU RAYA (1955-2019)
}

Fitriani, Andang Firmansyah, Astrini Eka Putri

Program Studi Pendidikan Sejarah FKIP Untan Pontianak Email: fitry.fitry98@gmail.com

\begin{abstract}
The research method used in this research is the historical research method (historical methodology). The steps used in the historical method consist of topic selection, heuristics, verification, interpretation, and historiography. From this research, it is concluded that the transmigration settlement was formed as a result of the transmigration program in 1955-1957. The aim of the transmigration program is to change the standard of living for the welfare of the transmigrants for the better. Each head of a transmigrant family gets 50 square meters of land for the yard, and one hectare for agricultural land as well as a 10-year living allowance. The hard work of transmigrants in adapting to the new environment is not easy. Developments in terms of social and economic development are quite developed, with the existence of community social activities that continue to run to maintain friendship between fellow people, although now many first generation transmigrants are no longer there, but most of the objects of transmigration are inhabited by descendants of transmigrants and live side by side with each other. with descendants of the original inhabitants as well as immigrants. In the economic field, the people who initially only made a living as farmers are now working as private employees, civil servants, TNI/POLRI. Although most of them still make a living as vegetable farmers or gardening, but now they are classified as successful farmers with a promising income every time they harvest.
\end{abstract}

Keywords: Social Development, Economic Development, Transmigration.

\section{PENDAHULUAN}

$\begin{array}{ccr}\text { Istilah } & \text { "transmigrasi" } & \text { yang } \\ \text { digunakan di } & \text { Indonesia } & \text { berarti }\end{array}$ pemindahan penduduk dari suatu daerah yang ditempati ke daerah lain yang telah ditetapkan di wilayah Republik Indonesia yang ditujukan untuk pembangunan bangsa atau untuk alasan yang dianggap perlu bagi pemerintah, Hardjono (1977, p.
14). Penanganan transmigrasi dilalakukan untuk lebih memajukan kesejahteraan dan peran serta masyarakat, pemerataan pembangunan daerah, dan memperkuat persatuan dan kesatuan bangsa melalui persebaran penduduk yang seimbang dengan daya dukung alam dan daya tampung lingkungan serta nilai budaya dan adat istiadat masyarakat (UU RI No 
29 Tahun $2009 \quad$ Tentang Ketransmigrasian). Transmigrasi dapat dikatakan sebagai perpindahan penduduk dari daerah yang padat, ke daerah yang tidak padat penduduknya upaya pemerintah untuk pemerataan penduduk dan pembangunan daerah.

Program transmigrasi sudah berlangsung sejak pemerintahan Belanda pada abad ke-19. Belanda mulai membuka hati dan pikiran untuk bersikap lebih manusiawi terhadap penduduk di wilayah jajahannya, Swasono (1986, p. 8). Akan tetapi cara Belanda memerintah masih tetap otoriter, hanya otokrasinya menjadi agak layak, merekamulai memikirkan kemakmuran dan pendidikan rakyat. Menurut Firmansyah (2018, p. 380) dalam artikelnya memaparkan bahwa "Tujuan mereka mengadakan program transmigrasi adalah untuk membangun desa-desa dengan jumlah penduduk 500 KK setiap desanya, penduduk desa diberi bantuan secukupnya agar ekonomi mereka cepat meningkat dan selanjutnya desadesa ini diharapkan akan bisa menjadi basis bagi kolonis baru untuk membuka daerah sekitarnya. Pada saat pemerintahan Soekarno transmigrasi pertama diadakan pada bulan Desember 1950. Program ini di selenggarakan oleh Dinas Transmigrasi (Jawatan Transmigrasi)". Jawatan Transmigrasi berada di bawah kementerian sosial. Pada tahun 1960, layanan ini telah bergabung dengan Departemen Koperasi, sehingga menjadi Departemen Transmigrasi dan Koperasi (Heeren. 1979).

Jika dilihat dari awal dibukanya daerah transmigrasi di Dusun Sidomulyo Desa Limbung, diperkirakan sudah mencapai 60an tahun lamanya pembangunan di desa tersebut berjalan. Seharusnya pembangunan desa ini sudah sangat maju bahkan menjadi kategori desa mandiri meskipun tolak ukur untuk mengetahui desa itu mandiri, maju, berkembang bahkan tertinggal ada nilai atau variabel Indeks Desa Membangun
(IDM), sebagaimana terlampir dalam Permendesa Nomor 2 Tahun 2016 tentang IDM. Namun tidak ada salahnya jika mempunyai penilaian sendiri tentang kategori desa, seperti yang kita tahu kategori desa maju yaitu desa yang memiliki potensi sumber daya sosial, ekonomi dan ekologi, serta kemampuan mengelolanya untuk peningkatan kesejahteraan masyarakat desa, kualitas hidup manusia, dan menanggulangi kemiskinan. Akan tetapi hingga saat ini desa tersebut masih menjadi desa berkembang yang memiliki potensi sumber daya sosial, ekonomi, dan ekologi tetapi belum bisa mengolahnya secara optimal untuk peningkatan kesejahteraan masyarakat desa.

Dibandingkan dengan desa-desa daerah transmigrasi lainnya yang belum terlalu lama. Seperti halnya transmigrasi Desa Rasau Jaya yang sekarang sudah menjadi desa mandiri padahal usia transmigrasi Rasau Jaya jauh lebih muda dari Dusun Sidomulyo Desa Limbung. Melihat dari letak desa ini tidak terlalu jauh dari kota Pontianak, lokasinya sangat dekat dengan Bandara Supadio tidak membuat desa ini menjadi desa yang pembangunannya secara masif atau meningkat. Terlebih lagi pembangunan pada jalan, sangat belum optimal masih banyak jalur yang rusak, bahkan rusaknya sudah bertahun-tahun lamanya tetapi tidak ada perbaikan. Untung saja ada penerangan lampu listrik yang menerangi jalan yang rusak pada malam hari, akan tetapi masih ada jalan yang belum ada penerangan listriknya sehingga menyulitkan jika melewati jalan tersebut pada malam hari terlebih apabila kendaraan yang digunakan tidak ada lampu penerangannya.

Untuk lahan-lahan pembagian dari pemerintah saat pertama kali transmigrasi dahulu sekarang sudah jarang yang kosong, lahan-lahan itu di bangun rumah keturunan mereka. Bangunan rumah berbahan kayu dari pemerintah juga sudah 
jarang di jumpai di desa ini, rumah-rumah tersebut sudah bergantikan dengan bangunan megah dari semen dan juga keramik. Untuk persoalan pendidikan masyarakat disini sudah mulai membaik jika sebelumnya mereka jarang melanjutkan sekolah hingga SMA/sederajat, hanya sampai SMP sudah langsung terjun ke dunia kerja dan menikah di usia yang sangat muda. Sekarang masyarakat lebih mementingkan pendidikan meskipun untuk mencapai jenjang perkuliahan masih sangat jarang, bisa terhitung jari yang hingga bangku kuliah. Mata pencaharian masyarakat disini juga sudah banyak berubah, yang awalnya mata pencaharian mereka bertani sekarang mereka lebih memilih mengadu nasib di kota karena jarak desa dengan kota Pontianak tidak terlalu jauh. Mereka berfikir berkerja sebagai petani memerlukan waktu yang lama untuk mendapatkan hasil itupun kalau hasil panen tidak gagal. Akan tetapi untuk masyarakat asli transmigrasi yang masih hidup hingga saat ini mereka sudah tidak bekerja dikarenakan sudah tua, hanya kadang-kadang mereka masih ke ladang/sawah menanam umbi-umbian sebagai hiburan untuk menghilangkan rasa bosan di rumah.

Daerah transmigrasi ini cukup sepi jarang toko-toko, jadi masyarakat lebih memilih belanja bahan-bahan makanan pokok di luar (Kuala Dua/Pontianak). Lingkungan terbantu keramaiannya dengan adanya developer/pengembang yang mendirikan perumahan sekitar tahun 2010, perumahan ini merupakan perumahan pertama dan satu-satunya yang ada di daerah transmigrasi ini. Dengan adanya perumahan ini berarti ada penambahan masyarakat di desa ini dari berbagai daerah dan karakter yang mempengaruhi masyarakat transmigrasi itu sendiri, mereka juga mendapatkan keuntungan dengan adanya pengembang yang bisa membantu sebagian masyarakat untuk mencari pundi-pundi rupiah dengan ikut bekerja mendirikan perumahan. Hal ini menjadi perubahan masyarakat yang awalnya bergerak di bidang agraris/petani menjadi bergerak di bidang jasa non agraris. Dengan adanya masyarakat perumahan memberikan pengaruh kepada masyarakat transmigran yang awalnya masyarakat transmigran bercirikan masyarakat pedesaan/paguyuban dengan mementingkan kepentingan kelompok (bersama) yang lebih diutamakan dibandingkan kepentingan pribadi masing-masing. Menurut Soekanto (2009, p. 116), Tonnies membedakan masyarakat paguyuban (gemeinschaft) menjadi 3 jenis yaitu: ikatan darah, tempat tinggal, ideologi/pikiran. Perlahan masyarakat mulai berubah menjadi masyarakat kota/patembayan yang mementingkan kepentingannya untuk mencapai tujuan dari masing-masing individu (diri sendiri), tanpa memperdulikan kepentingan kelompok meskipun tidak sepenuhnya menjadi masyarakat patembayan, karena sebagian besar masih mau mengadakan kegiatan gotong-royong, kegiatan keagamaan bersama, dan juga masih sering menampilkan seni tradisional saat ada selamatan nikahan dan lain-lain.

\section{Kajian Pustaka}

\section{Masyarakat}

Masyarakat merupakan sekumpulan manusia didalam suatu bagan semi tertutup ataupun semi terbuka yang diantaranya terjadi interaksi antar perorangan-perorangan yang bebeda dengan kelompok itu. Kata "masyarakat" berasal dari kata didalam bahasa Arab yaitu musyarak. Secara abstrak, sebuah masyarakat adalah suatu jaringan hubungan antar entitas-entitas. Masyarakat merupakan sebuah komunitas yang saling tergantung satu sama lain. Adapun masyarakat menurut KKBI adalah sejumlah manusia dalam arti seluas-luasnya dan terikat oleh suatu kebudayaan yang mereka anggap sama.

Menurut Koenjaraningrat (2009, p. 115), masyarakat adalah kesatuan hidup 
manusia yang berinteraksi menurut suatu sistem adat istiadat tertentu yang bersifat kontinue, dan yang terikat oleh suatu rasa identitas bersama. Kontinuitas merupakan kesatuan masyarakat yang memiliki keempat ciri, yaitu: interaksi antar warga, adat istiadat, kontiunitas waktu, rasa identitas kuat yang mengikat semua warga. Iver dan Page (Soekanto, 2009, p. 2) memaparkan bahwa masyarakat adalah suatu sistem dari kebiasaan, tata cara, dari wewenang dan kerja sama antaara berbagai kelompok, penggolongan, dan pengawasan tingkah laku serta kebiasaankebiasaan manusia.

\section{Transmigrasi}

\section{a) Pengertian Transmigrasi}

Transmigrasi secara etimologi
berasal dari bahasa Latin:
transmigratus, yang setelah diadobsi
oleh bahasa Inggris lalu menjadi
transmigration dari akar kata migrate
yang berarti berpindah tempat.
Transmigrasi kemudian berkembang
secara generik yang berarti
perpindahan dan atau pemindahan
penduduk dari satu daerah ke daerah
lain, atau dari satu pulau ke pulau
lainnya. Jadi dalam artian sederhana
bahwa transmigrasi adalah
perpindahan penduduk dari suatu
tempat yang penduduknya padat ke
daerah yang penduduknya kurang
padat. Adapun menurut Kamus Besar
Bahasa Indonesia (KKBI) merupakan
perpindahan penduduk dari suatu
daerah (pulau) yang penduduknya
ramai ke daerah (pulau) lain yang
berpenduduk jarang.

Menurut Asnaini (2009, p. 7), transmigrasi di Indonesia sudah ada pada masa penjajahan Belanda yang dimulai sejak tahun 1905 dan berlangsung hingga tahun 1942. Pada masa itu transmigrasi atau perpindahan penduduk dikenal dengan istilah kolonisasi. Sehingga bisa dikatakan juga bahwa transmigrasi merupakan kolonisasi yang awal mulanya dicetuskan oleh Belanda, perpindahan penduduk ini dimaksudkan untuk membuka daerah kolonis baru. Transmigrasi menurut Heeren (1979 , p. 6) adalah perpindahan, dalam hal ini memindahkan orang dari daerah yang padat ke daerah yang tidak padat penduduknya dalam batas negara dalam rangka kebijaksanaan nasional untuk tercapainya penyebaran penduduk serta meningkatkan kesejahteraan masyarakat.

\section{b) Jenis-jenis Transmigrasi}

Keikutsertaan masyarakat dalam program transmigrasi di dasarkan pada prinsip sukarela dan dapat memilih jenis serta pola usaha yang sesuai dengan aspirasi dan kemampuan masing-masing. Mirwanto (2004, p. 41) membagi transmigrasi menjadi tiga jenis yaitu :

a. Transmigrasi Umum (TU), yaitu jenis transmigrasi yang sepenuhnya diselenggarakan oleh pemerintah. Artinya, keseluruhan proses pelaksanaan transmigrasi menjadi tanggung jawab pemerintah, sedangkan transmigran mendapat bantuan jika mungkin butuh bantuan akan mendapat subsidi dari pemerintah.

b. Transmigrasi Swakarsa Berbantuan (TSB), yaitu transmigrasi yang dirancang oleh pemerintah dan dilaksanakan bekerjasama dengan Badan Usaha. Peranan pemerintah yaitu menolong dalam batas tertentu agar kemitrausahaan Badan Usaha dengan transmigran berjalan setara, adil dan berkesinambungan, agar kedua pihak saling memperoleh keuntungan.

c. Transmigrasi Swakarsa Mandiri (TSM), yaitu jenis transmigrasi yang sepenuhnya merupakan prakarsa transmigran yang 
dilakukan secara perseorangan atau kelompok, baik melalui kerjasama dengan Badan Usaha maupun sepenuhnya dikembangkan oleh transmigran yang bersangkutan.

Berdasarkan pelaksanaannya, transmigrasi dapat dibedakan menjadi, sebagai berikut :

a. Transmigrasi Umum, yaitu transmigrasi yang dilakukan yang dilakukan melalui program pemerintah. Biaya transmigrasi ditanggung pemerintah, termasuk penyediaan lahan pertanian dan biaya hidup untuk beberapa bulan

b. Transmigrasi Spontan, merupakan transmigrasi yang dilakukan atas kesadaran dan biaya sendiri (swakarsa).

c. Transmigrasi Sektoral, yaitu transmigrasi yang biayanya ditanggung bersama antara pemerintah daerah asal dan pemerintah daerah tujuan transmigrasi.

d. Transmigrasi Bedol Desa, yaitu transmigrasi yang dilakukan terhadap satu desa atau daerah secara bersama-sama.

\section{Perkembangan Sosial}

Perkembangan (development) merupakan bertambahnya kemampuan (skill) dalam struktur serta guna badan yang lebih kompleks dalam pola yang tertata serta bisa diramalkan, selaku hasil dari proses pematangan. Perkembangan menyangkut terdapatnya proses diferensiasi dari sel- sel badan, jaringan badan, organorgan serta sistem organ yang berkembang sedemikian rupa sehingga masing- masing bisa penuhi peranannya (Jahja, 2011, p. 28)

Hartinah (2008, p. 24) menuturkan jika ada bermacam ragam pengertian yang berkesinambungan dengan perkembangan. Perkembangan merupakan proses transformasi kualitatif yang mengacu pada mutu guna organ- organ jasmani serta bukan pada organ jasmani tersebut sehingga penekanan makna perkembangan terletak pada penyempurnaan guna psikologis yang termanifestasi pada keahlian organ fisiologis. Proses perkembangan hendak berlangsung selama kehidupan manusia, sebaliknya proses pertumbuhan kerapkali hendak menyudahi bila seseorang sudah menggapai kematangan fisik.

Kata sosial berasal dari bahasa latin yaitu 'sosius' yang artinya semua yang terlahir, tumbuh, dan berkembang dalam kehidupan bersama (Salim, 2002). Menurut Sudarno (dalam Salim, 2002, p. 12) menekankan pengertian sosial pada strukturnya, yaitu suatu tatanan dari hubungan-hubungan sosial dalam masyarakat yang menempatkan pihak-pihak tertentu (individu, keluarga, kelompok, kelas) di dalam golongan sosial tertentu berdasarkan suatu sistem nilai $\&$ adab yang berlaku pada suatu masyarakat pada waktu tertentu.

Menurut Hurlock (2011, p. 250), perkembangan sosial merupakan pendapatan tingkah-laku yang cocok dengan pedoman sosial. Menjadi manusia yang dapat bersosialisasi (sozialized) membutuhkan 3 tahapan. Tiap-tiap fase terpisah dan amat berlainan dengan lainnya, tetaapi saling terikat, akibatnya kegagalan dalam suatu proses akan menurunkan kadar sosialisasi individu.

\section{Perkembangan Ekonomi}

Menurut Prof. Simon Kuznets dalam (Todaro, 2000, p. 44) pertumbuhan merupakan kapasitas jangka panjang dari negara yang bersangkutan untuk menyediakan berbagai barang ekonomi kepada 
penduduknya. Kenaikan kapasitas tersebut dimungkinkan oleh adanya kemajuan atau penyesuaian teknologi dan ideologi terhadap berbagai keadaan.

Perkembangan ekonomi sendiri berartian cukup luas dan mencakup perubahan dalam tahapan ekonomi yang umumnya diartikan dengan suatu proses yang menyebabkan naiknya pendapatan rill perkapita penduduk suatu daerah dalam jangka waktu yang lama.

Pembangunan ekonomi yaitu suatu metode yang berartian perubahan yang terjadi terus menerus, usaha untuk menaikkan pendapatan perkapita, kenaikan pendapatan perkapita harus terus berlangsung dalam jangka panjang dan yang terakhir perbaikan sistem kelembagaan disegala bidang (Arsyad, 1999, p. 12).

\section{Metode Penelitian}

Metode dalam studi sejarah adalah serangkaian pedoman dan pilar terstruktur saat mengumpulkan sumber-sumber sejarah secara terstruktur, memilahnya dengan kritis, dan mengajukan sintesis secara tertulis (Hamid dan Madjid, 2015, p. 42). Menurut Gootschalk (1969, p. 32) memaparkan bahwa "prosedur sejarah merupakan metode mengevaluasi serta menganalisis secara kritis rekaman serta peninggalan masa lampau" atau menurut Arikunto (2010, p. 252) memaparkan bahwa "penelaahan dokumen serta sumber-sumber lain yang berisi informasi masa lampau dan dilakukan secara sistematis.

Riset ini memakai prosedur riset sejarah yang terdiri dari 5 tahapan, yakni: pemilihan topik, heuristik, verifikasi (kritik sumber), interpretasi, serta historiografi ( Kuntowijoyo, 2013, p. 64).

Tahapan riset bagi Kuntowijoyo yakni sebagai berikut:

\section{Pemilihan Topik}

Pemililihan topik merupakan tahap awal untuk melaksanakan riset sejarah. Bertujuan supaya saat penerapan mencari sumber-sumber sejarah bisa terencana serta pas pada permasalahan yang hendak diteliti. Pada suatu riset, topik wajib diseleksi bersumber pada keakraban emosional serta keakraban intektual. Ketentuan tersebut sangat berguna karena seorang akan bekerja dengan baik bila dia bahagia serta sanggup melaksanakannya

Peneliti mengambil topik tentang Perkembangan Sosial Ekonomi Masyarakat Transmigrasi di Dusun Sidomulyo Desa Limbung Kecamatan Sungai Raya Kabupaten Kubu Raya (1955-2019) dikarenakan pada saat itu transmigrasi mulai masuk ke daerah Dusun Sidomulyo untuk pertama kalinya sehingga peneliti sangat tertarik untuk melakukan penelitian ini untuk mengetahui perkembangan sosial ekonomi masyarakat transmigran di daerah ini.

\section{Heuristik}

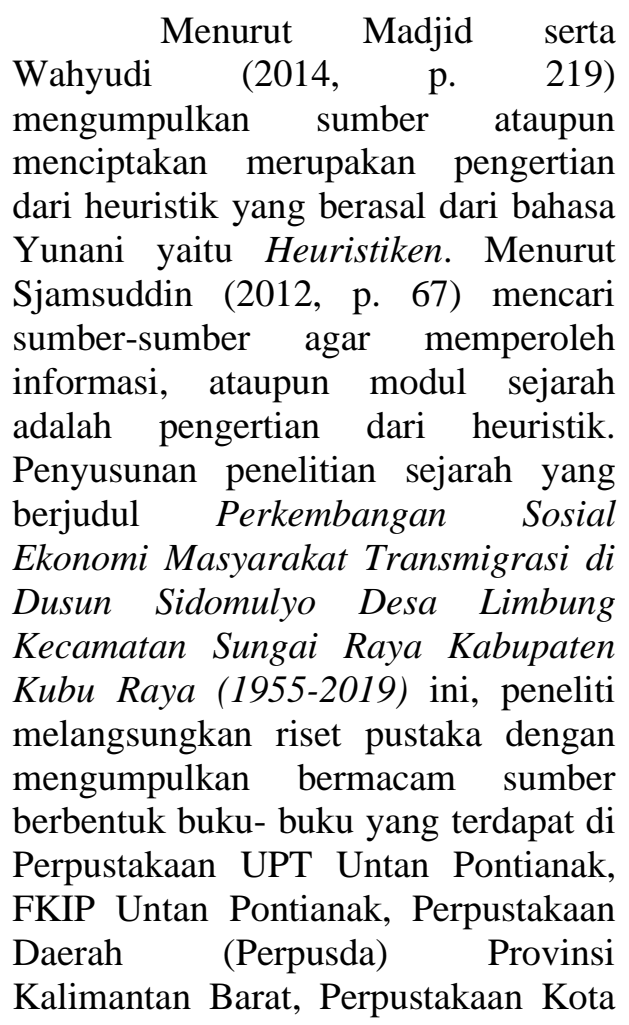


Pontianak, Balai Pelestarian Nilai Budaya( BPNB) Pontianak, Perpustakaan IKIP- PGRI Pontianak, IAIN Pontianak, serta Universitas Muhammadiyah Pontianak. Klarisifikasi sumber sejarah dipisah menjadi dua yakni selaku berikut.

\section{Sumber Primer}

(Gottschalk, 1969, p. 35) mengungangkapkan sumber primer merupakan kesaksian langsung dengan mata kepala sendiri ataupun panca indera lainnya, ataupun dengan perkakas yang ada saat kejadian yang diceritakannya dan diucapkan selaku saksi mata atau dikenal dengan perlengkapan mekanis semacam diktafon..

Selain sumber primer tertulis ataupun lisan ada juga sumber primer yang lainnya yaitu wawancara langsung dengan naearumber. Berikut narasumber yang didapatkan di lapangan dalam penelitian ini. .

-Bapak Giman, pelaku transmigrasi desa setempat.

- Bapak Rebo, selaku kepala dusun setempat pada masanya.

-Bapak Mijo, pelaku transmigrasi

-Bapak Keman, pelaku transmigrasi

-Bapak Sidiq, pelaku transmigrasi

-Bapak Selamet, masyarakat asli lokasi transmigrasi

2. Sumber Sekunder

Menurut Gottschalk, (1969, p. 35), sumber sekunder yaitu kesaksian seseorang yang tidak ada di tempat kejadian yang di ceritakan ataupun bukan merupakan saksi langsung atau tidak melihat secara langsung peristiwa itu. Sumber sekunder yang digunakan dalam penulisan penelitian ini dengan kajian pustaka yang berasal dari karya ilmiah sarjana lainnya juga beberapa sejarawan atau juga penelitian dan buku-buku yang mengangkat masalah yang sama ataupun dengan kedekatan yang sama. Dengan itu, maka peneliti menggunakan beberapa sumber sekunder sebagai berikut.

Andriati, R.D. 2015. Transmigrasi Masa Doeloe, Kini dan Harapan Kedepan : Kementerian Desa, Pembangunan Daerah Tertinggal dan Transmigrasi RI.

Asnaini. 2009. Transmigrasi di SP8 Desa Belaban Tujuh Kecamatan Tumbang Titi Kabupaten Ketapang. Pontianak: Balai Pelestarian Sejarah dan Nilai Tradisional Pontianak.

Suparno, 2007. Paradigma Baru Transmigrasi Мепији Kemakmuran rakyat. Departemen Tenaga Kerja dan Transmigrasi Republik Indonesia. Jakarta.

Heeren, H. J. (1979). Transmigrasi di Indonesia. Jakarta: Gramedia.

\section{Verifikasi (Kritik sumber)}

Kritik sumber (verifikasi) merupakan kegiatan guna meninjau, memilah dan memulai mengelompokkan kebenaran dengan sumber yang sudah ditemui cocok dengan objek riset (Kuntowijoyo, 2005, p. 100). Dalam prosedur sejarah diketahui dengan metode menerapkan kritik ekstern serta kritik intern (Sjamsuddin, 2012, p. 104).

Bagi (Daliman, 2015) kritik sumber bisa bisa dicoba dari dua sudut pandang yakni:

a. Kritik Ekstern (Keautentikan) 
Kritik ekstern merupakan kritik guna menguji keautentikan (keaslian) sesuatu sumber, supaya diperoleh sumber yang serius asli bukannya tiruan ataupun palsu. Sumber yang aslinya umumnya waktu serta tempatnya dikenal.

b. Kritik Intern (Kredibilitas)

Kritik Intern maksudnya pengamat ataupun sejarawan wajib memastikan seberapa jauh sumber bisa dipercaya (credible ataupun reliable) kebenaran dari isi data yang di informasikan oleh sesuatu sumber ataupun dokumen sejarah (Daliman, 2015, p. 66-72).

\section{Interpretasi}

Sjamsuddin, (2012, p. 123) menjelaskan bahwa kebenaran history yang dibesarkan sebagai kesatuan yang utuh serta bermakna yang logis merupakan pengertian interpretasi. Sesi interpretasi ialah bidang dari subjektif sejarawan itu sendiri. Menuurut Kuntowijoyo, (2005, p. 101), subjektif sejarawan memanglah diakui namun wajib dihindari. Ada dua ragam Interpretasi, ialah analisis yaitu menguraikan serta sintesis yaitu menggabungkan (Sjamsuddin, 2012, p. 123).

Terkadang fakta yang ditemui condong ke salah satu pelakon sejarah, sehingga sejarawan wajib dapat memandang dua sisi dari sesuatu kejadian guna menjauhi subjektifitas. Pengamat berupaya bersikap netral serta menafsirkan fakta yang di peroleh di lapangan untuk pengkajian Perkembangan Sosial Ekonomi Masyarakat Transmigrasi di Dusun Sidomulyo Desa Limbung Kecamatan Sungai Raya Kabupaten Kubu Raya( 1955-2019).

\section{Historiografi}

Historiografi ialah sesi akhir dari riset sejarah, sesudah melalui fasefase pemilihan topik, heuristik, verifikasi (kritik sumber) serta interpretasi. Penyusunan sejarah( historiografi) merupakan metode penyusunan, menjelaskan, ataupun pelaporan hasil riset sejarah yang sudah dicoba (Madjid dan Wahyudi, 2014, p. 230).

Dengan memakai tata cara sejarah serta historiografi sejarawan berupaya guna melakukan pembaharuan yang banyak dari masa lampau manusia. Namun dalam keterbatasan, sejarawan banyak menghadapi kesulitan-kesulitan . Tidak sering kali bisa diceritakan sepenggal sekalipun dari masa lalu (Gottschalk, 1985, p. 39).

\section{PEMBAHASAN}

Gambaran Umum Dusun Sidomulyo Desa Limbung Kecamatan Sungai Raya Kabupaten Kubu Raya

\section{A. Letak Geografis}

Desa Limbung merupakan salah satu desa di Kecamatan Sungai Raya Kabupaten Kubu Raya, yang mempunyai luas daerah kurang lebih $45 \mathrm{~km}^{2}$. Berdasarkan posisi geografis Desa Limbung memiliki batas-batas:

Timur : Desa Arang Limbung

Selatan : Desa Kuala Dua

Barat : Desa Rasau Jaya dan Desa Punggur

Utara : Sungai Kapuas dan Desa Sungai Ambangah

Jika di lihat kondisi geografis Desa Limbung memiliki topografi dataran rendah, suhu rata-rata sebesar $20^{\circ}-30^{\circ} \mathrm{C}$ dengan kondisi tanah yang putih dan bergambut. Jarak pusat Pemerintah Desa dari pusat Pemerintah Kecamatan sejauh $3 \mathrm{~km}$, pusat Pemerintah Kabupaten sejauh $2 \mathrm{~km}$, pusat Pemerintah Provinsi sejauh 9 $\mathrm{km}$. 
Pada tahun 2002 Desa Limbung melakukan pemekaran menjadi desa sendiri dari hasil pemekaran Desa Arang Limbung, dengan perangkat desa yaitu satu orang Sekdes, 3 orang Kasi, 4 orang Kepala Dusun, 10 orang bendahara desa. Jumlah rukun warga (RW) sebanyak 10 RW, rukun tetangga (RT) sebanyak 65 RT. Desa Limbung mempunyai 4 dusun yaitu Dusun Sidomulyo, Dusun Mulyorejo, Dusun Merdeka, dan Dusun Limbung Jaya. Salah satu dusunnya yaitu Dusun Sidomulyo merupakan tempat dimana objek transmigrasi Sungai Durian.

Sumber: www.kuburayakab.go.id

\section{B. Demografi}

Pada tahun 2010 jumlah penduduk Desa Limbung menurut umur dan jenis kelamin berjumlah 14.357 jiwa, yang terdiri dari 7.414 laki-laki dan 6.943 perempuan dari golongan usia 0-65 tahun keatas. Jumlah penduduk laki-laki masih lebih banyak dibandingkan perempuan akan tetapi, jumlah peningkatan penduduk perempuan lebih banyak dibandingkan laki-laki. Pada tahun 2019 terjumlah 17.076 jiwa, terdiri dari laki-laki 8.791 jiwa dan perempuannya 8.285 jiwa. Kepadatan penduduk di Desa Limbung tahun 2019 yaitu $1.275 \mathrm{jiwa} / \mathrm{km}^{2}$, dengan luas wilayah $13,39 \mathrm{~km}^{2}$.

Transmigrasi Di Dusun Sidomulyo Desa Limbung Kecamatan Sungai Raya Kabupaten Kubu Raya Tahun 19551957

\section{A. Awal kedatangan Transmigran di Dusun Sidomulyo Desa Limbung}

Transmigrasi di Dusun Sidomulyo merupakan transmigrasi pertama di Borneo (Kalimantan) yaitu pada tahun 1955. Proses transmigrasi dari Jawa ke Kalimantan hingga sampai ke Dusun Sidomulyo berbulanbulan lamanya. Dari masih diperjalanan berangkat, karena seharusnya transmigrasi ini tujuannya bukan ke Kalimantan, akan tetapi ke Palembang.

Awal mulanya tempat lokasi transmigrasi ini masih bergabung dengan Desa Sungai Durian (bagian darat), seperti pada dokumen-dokumen atau pun jurnal-jurnal transmigrasi menyebutkan bahwa lokasi tempat para transmigran ialah Sungai Durian Desa Limbung, yang kini lebih dikenal dengan desa objek transmigrasi Dusun Sidomulyo. Nama Dusun Sidomulyo juga masih baru sekitar tahun 2002 sebelumnya daerah ini tergabung dalam Dusun Mulyorejo Desa Arang Limbung.

Setelah ada pemekaran desa pada tahun 2002 menjadi Desa Limbung dan mempunyai 4 dusun yaitu Dusun Sidomulyo, Dusun Mulyorejo, Dusun Limbung Jaya, dan Dusun Merdeka. Nama Dusun Sidomulyo pertama kali di cetuskan oleh Pak Mulyoto salah satu sesepuh di Dusun Sidomulyo, saat rapat pembentukan dusun. . Sidomulyo berasal dari bahasa Jawa Timur yang terdiri dari dua kata yaitu "Sido" yang berarti jadi atau menjadi, dan "Mulyo" yang berarti mulia atau sejahtera, dengan harapan daerah ini menjadi sejahtera.

Para transmigran yang datang ke Dusun Sidomulyo, Desa Limbung secara bertahap dalam 3 kelompok gelombang pemberangkatan dari tahun 1955 sampai dengan tahun 1956. Setiap kepala keluarga transmigran mendapat lahan seluas 500 meter di bukakan pemerintah untuk pekarangan rumah, dan satu hektar untuk lahan pertanian, akan tetapi tanahnya masih di tengah hutan. Lokasi transmigrasi masih berupa hutan yang sebagian sudah di bersihkan dan di bangun rumah untuk para transmigran gelombang pertama yakni dari patok nol sampai dengan patok sepuluh. 
Rumah yang tersedia pun seadanya yang terbuat dari kulit kayu dan pohon nipah (sejenis pohon palem) sebangai dindingnya, serta daun nipah digunakan sebagai atapnya dengan ukuran 4 x 6 meter persegi.

\section{B. Adaptasi Masyarakat Transmigrasi Dengan Lingkungan Transmigrasi Tahun 1955-2019}

Menyesuaikan diri bisa dimaksud selaku ikatan penyesuaian antara organisme dalam kawasan sebagai totalitas yang terdapat di dalam ornasime itu sebagai bagiannya. Dalam menyesuaikan diri dengan area, sebaiknya seorang membawa dan kaidah-kaidah yang mengatur perilaku serta kedudukan yang diperankannya (Daeng, 2008, p. 44).

Pada dikala awal kali Mbah Giman (87th) menginjakkan kakinya didaerah penempatan transmigrasi berkata kalau dia merasa sangat pilu sebab tak betah menempuh kehidupannya yang masih serba terbatas, serta waktu itu Mbah Giman (87th) masih seseorang bujangan serta seseorang diri di tempat baru. Pernah terselip kemauan guna kembali ke Jawa namun sebab tidak mempunyai uang, dengan kesabaran serta ketabahan hingga Mbah Giman (87th) memilih senantiasa bertahan hingga saat ini.

Keadaan yang demikian, para transmigran hadapi proses menyesuaikan diri di bumi rantau. Bagi mereka seperti apa terpencilnya desa mereka di tanah Jawa, cukup terbilang nyaman bila dibanding hidup di perkampungan transmigrasi yang pernah membuat para transmigran berfikir untuk kembali kembali ke Pulau Jawa yang mereka anggap lebih baik dibanding hidup di tengah hutan Kalimantan. Tetapi seluruh perasaan itu cuma hanya keinginan saja sedangkan, lama kelamaan warga transmigrasi mulai terbiasa serta mulai dapat menyesuaikan diri dengan menerima kondisi wilayah pemukiman transmigrasi.

Disamping menyesuaikan diri dengan kondisi area, warga transmigran pula dituntut wajib dapat menyesuaikan diri dengan pemberian dari pemerintah, berupa tanah agar dapat memenuhi kebutuhan hidup dengan menanam atau betani guna bertahan hidup.

Bagi Pak Giman (87th), proses menyesuaikan diri antara transmigran serta penduduk asli telah terjalin lumayan erat semenjak tahun- tahun awal para transmigran tiba. Dengan terdapatnya asimilasi ialah perkawinan antara, warga transmigran dengan penduduk asli. Pak Giman (87th) pula menarangkan kalau pada dikala itu mayoritas masyarakat yang berkerja selaku tukang bangunan (membangun rumah) merupakan masyarakat setempat, selain itu mereka ada yang tertarik dengan anak gadis dari transmigran serta setelah itu terjadilah pernikahan.

Penyesuaian warga transmigran dan penduduk pendatang terhadap perubahan-perubahan faktor yang terjalin lumayan baik, semacam halnya bermacam faktor kebudayaan baik itu antar orang maupun antar warga. Selagi faktor kebudayaan itu tidak merugikan pihak mana pun, lamalama muncul pengakuan akan manfaat faktor kebudayaan tersebut.

Perihal ini menjadi contoh oleh kehidupan transmigran di Dusun Sidomulyo, meskipin pada awal mulanya mereka tidak memahami satu sama lain sebab satu pemukiman tempat tinggal tranmigran terdiri dari sekian banyak kepala keluarga yang tiba dari bermacam wilayah. Kecanggungan yang di alami di lingkungan transmigrasi, dapat dikalahkan sebab rasa senasib di tanah 
rantau lebih tinggi dan lebih cepat guna mengenal satu sama lain

\section{Interaksi Sosial Masyarakat Transmigran}

Interaksi pemduduk transmigrasi dan penduduk pendatang juga nampak saat ada agenda kemasyarakatan perihal memajukan desa, ataupun dalam bidang agama penduduk bertoleransi antar agama. Menurut Pak Rebo (77th) selaku kepala dusun pertama di Dusun Sidomulyo, bahwa desa ini merupakan desa yang tentram dan damai, yang dimaksudkan disini ialah tidak pernah terjadi konflik yang serius.

\section{Perkembangan \\ Masyarakat \\ Transmigrasi Di Dusun Sidomulyo Desa Limbung Kecamatan Sungai Raya Kabupaten Kubu Raya}

\section{A. Perkembangan Sosial Masyarakat Transmigran}

Seiring berjalannya waktu masyarakat sadar akan pentingnya pendidikan. Agar tercipta suatu bangsa yang hebat dan juga menentukan kualitas bangsa itu sendiri. Pendidikan juga faktor utama pembentukan pribadi manusia itu sendiri menurut ukuran normatif. Dengan pendidikan yang baik diharapkan dapat menciptakan generasi-generasi bangsa yang berkualitas dan cerdas.

Yang dulunya tidak ada sekolah di desa ini, sekarang sudah ada sekolah sampai tingkat SMA. Jadi tidak jauhjauh lagi untuk bersekolah, sekarang pun rata-rata warga memiliki kendaraan sepeda motor yang dapat digunakan untuk mengantar anaknya kesekolah. Sekarang tidak ada alasan lagi untuk bersekolah, karena pemerintah memiliki program pendidikan hingga 9 tahun atau setingkat SMP. Sekarang kalangan menengah kebawah pun bisa menikmati pendidikan.
Perkembangan sosial di Dusun Sidomulyo pada pendidikan menjadi suatu kebutuhan manusia untuk memajukan potensi sumber daya manusia yang sejalan dengan teknologi dan informasi. Untuk mencapai kebutuhan manusia tidak dapat dipisahkan dengan adanya campur tangan pemerintah pemerintah terkait dengan sarana dan prasarana ataupun tenaga pengajar yang profesional sehingga terjamin mutu dan kualitasnya sebagai gambaran tingkat pendidikan. Menjadikan masyarkat transmigrasi berlomba-lomba menyekolahkan anaknya dengan harapan dapat memperbaiki tingkat sosial dalam masyarakat (menjadi lebih terpandang). Dengan tingkatan sosial sesuai dengan kemampuannya ada yang menjadi petani dengan keahlian bertani, guru dengan kepandaian ilmu pendidikannya dan lain sebagainya.

\section{B. Perkembangan Ekonomi} Masyarakat Transmigrasi

Banyaknya masyarakat Dusun Sidomulyo yang bekerja di zona bercocok tanam ini dikarenakan masih banyak lahan pertanian di wilayah ini. Serta disebabkan dengan pekerjaan yang diwariskan oleh sesepuh mereka yang di dominasi dengan para generasi warga transmigrasi. Diantara mereka bermata pencaharian selaku petani, di dalam melaksanakan aktivitas bertani, ada juga dari mereka terdapat yang tidak mempunyai lahan sendiri, mereka ada yang menggarap tanah pertanian kepunyaan orang lain. Cuma sebagian kecil saja warga Dusun Sidomulyo yang mempunyai tanah sendiri, sebab kebanyakan warga yang tinggal disitu ialah generasi transmigran dari Jawa. Selebihnya warga itu tidak mempunyai lahan tergantung pada warga yang mempunyai lahan pertanian guna 
digarap ataupun yang kerap diucap dengan buruh tani.

Meskipun pertanian bukan satusatunya mata pencaharian masyarakat di Dusun Sidomulyo akan tetapi sebagian besar masyarakatnya mengadu nasib untuk bertahan hidup sehari-hari dengan bertani. Terlebih sekarang masyarakat lebih memilih menjadi pekerja buruh dengan alasan hasil yang didapat lebih cepat juga tidak panas-panasan di bawah sinar matahari. Sebagian masyarakat juga bermatapencaharian menjadi guru, TNI/POLRI, dokter, dan PNS. Taraf kehidupan ekonomi masyarakat transmigrasi di Dusun Sidomulyo sudah lebih baik dan mengalami peningkatan finansial.

Berkerja ialah kegiatan manusia untuk bertahan hidup serta untuk mendapatkan kehidupan yang lebih baik dengan berbagai macam dan ragamnya berbeda sesuai dengan skill dan tata geografi daerahnya. Dapat disimpulkan bahwa keanekaragaman status sosial ditunjukkan oleh perbedaan mata pencaharian yang berakibat dalam kemampuan.

Jika dilihat dari bangunan rumah, rata-rata bahkan hampir semua rumah yang mereka tinggali terbuat dari beton juga keramik dan beratapkan seng metal. Rumah yang terbuat dari kayu/papan bisa di hitung dengan menggunakan jari, sangat berbeda sekali pada saat para transmigran datang rumah mereka terbuat dari kulit kayu dan daun nipah. Untuk kendaraan yang dimiliki juga setiap rumah memiliki sepeda motor bahkan mobil. Sandang pangan setiap masyarakat sudah lebih baik dan mapan dari sebelumnya. Meskipun begitu dari data yang di dapat dari kepala dusun setempat masih cukup banyak KK yang mendapatkan bantuan Program Keluarga Harapan (PKH), ada yang berupa tunai maupun non tunai. Baik itu dari golongan ibu hamil/nifas, anak usia dini, pendidikan anak, penyandang disabilitas, lanjut usia.

\section{KESIMPULAN DAN SARAN}

\section{Kesimpulan}

Objek transmigrasi Dusun Sidomulyo terletak di Desa Limbung Kecamatan Sungai Raya Kabupaten Kubu Raya yang merupakan pemukiman hasil dari transmigrasi umum oleh pemerintah tahun 1955, 1956, 1957 oleh orang-orang dari Jawa Timur, Jawa Tengah dan Jawa Barat. Dusun Sidomulyo dikenal sebagai objek transmigrasi pertama di Borneo sejak tahun 2002, yang saat itu terjadi pemekaran Desa Limbung yang awalnya tergabung menjadi Desa Arang Limbung. Awal mulanya objek transmigrasi ini terkenal dengan sebutan Sungai Durian Darat.

Para Transmigran yang berasal dari Jawa Timur, Jawa Tengah, dan Jawa Barat. Tujuan para transmigran mengikuti program transmigrasi ialah agar bisa meningkatkan taraf kehidupan dan kesejahteraan para transmigran. Dengan Jumlah para transmigran kurang lebih 224 KK dan di berangkatkan secara bertahap, menjadi 3 tahap yaitu tahun 1955, 1956, 1957.

Perkembangan dalam berbagai bidang sosial di Dusun Sidomulyo mencerminkan bahwa masyarakat Dusun Sidomulyo adalah masyarakat yang damai. Dari segi pendidikan mulai banyak warga yang menempuh pendidikan tinggi hingga ke perguruan tinggi. Tingkat kesejahteraan masyarakat pun ikut membaik seiring berjalannya waktu. Kehidupan sosial yang awalnya masih Dari segi ekonomi kini masyarakat Dusun Sidomulyo tercukupi sandang, pangan serta tempat tinggal yang layak. Sidomulyo pada awal kedatangannya ke daerah transmigrasi hanya mengandalkan 
bantuan dari pemerintah dan jatah hidup. Hingga akhirnya mereka mulai secara perlahan untuk mengolah tanah gambut agar dapat ditanami tanaman pangan. Dengan Kesabaran dan kegigihan akhirnya kini keturunan masyarakat transmigran dapat menikmati hasilnya, sebagian besar dari mereka menjadi petani sukses dengan penghasilan setiap bulannya jutaan rupiah. Meskipun begitu tidak semua masyarakat bermatapencaharian sebagai petani, sebagian dari mereka ada yang menjadi karyawan swasta, buruh tani, PNS, TNI/POLRI dan lain-lain.

\section{Saran}

Diharapkan kepada masyarakat generasi transmigrasi agar terus berjuang memajukan Dusun Sidomulyo agar menjadi desa transmigrasi yang lebih maju lagi, karena dibandingkan desa transmigrasi yang jauh lebih muda dari Dusun Sidomulyo seperti Rasau Jaya, sangat lebih maju. Untuk pemerintah semoga lebih tergerak hatinya untuk membangun desa obyek transmigrasi tertua di Kalimantan Barat agar lebih maju, selain itu juga letaknya tidak jauh dari pusat kota. 


\section{DAFTAR RUJUKAN}

A, Daliman. (2015). Metode Penelitian Sejarah. Yogyakarta: Ombak.

Arikunto, S. (2010). Manajemen Penelitian. Jakarta: Rineka Cipta.

Arsyad, L. (1999). Ekonomi Pembangunan. Yogyakarta: STIE YKPN.

Asnaini. (2009). Transmigrasi di Sp-8 Desa Belaban Tujuh Kecamatan Tumbang Titi Kabupaten Ketapang. Pontianak: Balai Pelestarian Sejarah dan Nilai Tradisional Pontianak.

Daeng, H.J. (2008). Manusia, Kebudayaan dan Lingkungan. Yogyakarta: Pustaka Pelajar.

Firmasyah, A dkk. (2018). Pengalaman

Transmigrasi di Indonesia (Studi di Desa Olak-olak Kecamatan Kubu, Kabupaten Kubu Raya).Jurnal Historia
Volume 6, Nomor 2, ISSN 2327

-4713 (e-ISSN 2442-8728). 380.

Gottschalk, L. (1969). Mengerti Sejarah. Jakarta: UI-Press.

Hardjono, H.M. (1970). Transmigration In Indonesia. Kuala Lumpur. Jakarta: Oxford University Press.

Hamid, R dan Madjid M.S. (2015). Pengantar Ilmu Sejarah. Yogyakarta: Ombak.

Hartinah, S. (2008). Perkembangan Peserta Didik. Bandung: Refikka Aditama.

Heeren, H.J. (1979). Transmigrasi di Indonesia. Jakarta: Gramedia.

Hurlock, E.B. (2011). Psikologi Perkembangan: Suatu Pendekatan Sepanjang Rentang Kehidupan. Jakarta: Erlangga.

Kamus Pusat Pembinaan dan Pengembangan. (1993). Kamus Besar Bahasa Indonesia. Jakarta: Balai Pustaka.

Kuntowijoyo. (2005). Pengantar Ilmu Sejarah. Yogyakarta: Bentang Pustaka.

Koentjaraningrat. (2009). Pengantar Ilmu Antropologi. Jakarta: Rinneka Cipta.

Madjid, M.D dan Wahyudi J. (2014). Ilmu Sejarah Sebuah Pengantar. Jakarta: Predana Media.

Manuwiyoto, M. (2004). Mengenal dan Memahami Transmigrasi. Jakarta: Pustaka Sinar Harapan.

Sjamsuddin, H. (2019). Metodologi Sejarah. Yogyakarta: Ombak.

Soekanto, S. (2009). Sosiologi Suatu Pengantar. Jakarta: Rajawali Press.

Swasono, E dan Masari S. (1986). Transmigrasi di Indonesia 19051985. Jakarta: UI-Press.

www. kuburayakab.go .id. 